\title{
FENOMENA KEKERASAN GENDER DALAM NOVEL-NOVEL KARYA DANIELLE STEEL
}

\author{
Sylvie Meiliana \\ Fakultas Sastra Universitas Nasional \\ email: sylvie_surya@yahoo.com
}

\begin{abstract}
Abstrak
Penelitian ini bertujuan mendeskripsikan fenomena kekerasan gender dalam novelnovel karya Danielle Steel. Sumber data penelitian adalah tiga novel yang berjudul Malice, The Ghost, dan Journey. Analisis data menggunakan teknik analisis isi dengan model interaktif yang terdiri atas reduksi data, penyajian data, dan penarikan simpulan. Hasil penelitian sebagai berikut. Pertama, kekerasan gender mencakup: kekerasan fisik, psikis, dan seksual. Kedua, akar masalah kekerasan terhadap perempuan adalah: (a) ketimpangan gender, (b) penegakan hukum yang lemah, dan (c) dominasi nilai-nilai patriarki.
\end{abstract}

Kata kunci: gender, kekerasan fisik, psikis, dan seksual, dominasi nilai patriarki

\section{GENDER VIOLENCE PHENOMENA IN DANIELLE STEEL'S NOVELS}

\begin{abstract}
The study aims to describe gender violence phenomena in Danielle Steel's novels. The data sources were his three novels entitled Malice, The Ghost, and Journey. The data analysis was content analysis using the interactive model consisting of data reduction, data display, and conclusion drawing. The findings are as follows. First, gender violence includes physical, psychological, and sexual violence. Second, the causes of violence against women are: (a) gender discrimination, (b) weak law enforcement, and (c) dominance of patriarchal values.
\end{abstract}

Keywords: gender violence; physical, psychological, and sexual violence; dominance of patriarchal values

\section{PENDAHULUAN}

Kekerasan gender, khususnya kekerasan terhadap perempuan sampai saat ini masih merupakan sebuah fenomena sosial di dalam kehidupan masyarakat yang semakin hari semakin mengkhawatirkan. Sebagai isu global yang memerlukan penanganan khusus, deklarasi PBB telah menetapkan kekerasan terhadap perempuan merupakan kekerasan gender yang telah menyebabkan penderitaan fisik, psikis, dan seksual terhadap perempuan, termasuk ancaman bagi kemerdekaannya baik di dalam kehidupan pribadi maupun masyarakat (Coomaraswamy, 2008:2).
Kekerasan terhadap perempuan menurut Madsen (2000:2) sebagai akibat adanya anggapan bahwa inferioritas perempuan merupakan keturunan yang ditandai oleh fisik yang lemah, keterbatasan intelektual, dan kecenderungan pada emosi. Anggapan inilah yang kemudian menimbulkan pendapat bahwa perempuan bertugas dalam pekerjaan rumah tangga. Keadaan yang terjadi di dalam masyarakat ini kemudian melahirkan pendapat bahwa laki-laki superior karena perannya sebagai pencari nafkah dan pemimpin dengan aktivitas mereka di luar rumah. Sebaliknya, perempuan yang 
hanya tinggal di rumah dengan perannya sebagai ibu rumah tangga adalah kelompok inferior (Mascia, 2000:5). Keadaan ini kemudian menyebabkan kekerasan gender yang dilakukan laki-laki terhadap perempuan.

Kekerasan gender telah mengakibatkan hal-hal yang tidak menyenangkan seperti pembunuhan, penyiksaan, dan pencerahan terhadap perempuan baik secara fisik, psikis, seksual, maupun ekonomi. Ini adalah salah satu pelanggaran hak asasi manusia yang paling nyata karena telah terjadi pengingkaran terhadap kesetaraan dan hak yang sama antara lakilaki dan perempuan (Coomaraswamy, 2008: 2).

Sebuah artikel yang diterbitkan oleh pusat penelitian UNICEF dengan judul Domestic Violence Against Women and Girls mengungkapkan bahwa deklarasi PBB telah menetapkan bahwa kekerasan terhadap perempuan merupakan kekerasan gender yang telah menyebabkan penderitaan fisik, seksual dan psikologis terhadap kaum perempuan, termasuk ancaman bagi kemerdekaannya baik di dalam kehidupan pribadi maupun masyarakat (Coomaraswamy, 2008: 2).

Kekerasan pada dasarnya berasal dari berbagai sumber, salah satu kekerasan terhadap satu jenis kelamin tertentu, yaitu kaum perempuan disebabkan oleh anggapan gender. Menurut Oakley (Fakih, 2007:71-72) gender berarti perbedaan yang bukan biologis dan bukan kodrat Tuhan. Perbedaan yang bukan biologis yakni perbedaan jenis kelamin (sex) adalah kodrat Tuhan dan oleh karenanya secara permanen berbeda. Gender adalah perbedaan perilaku (behavioral differences) antara lakilaki dan perempuan yang dikonstruksi secara sosial, yakni perbedaan yang bukan kodrat atau bukan ketentuan Tuhan melainkan diciptakan oleh manusia (laki-laki dan perempuan) melalui proses sosial dan kultural yang panjang. Oleh karena itu, gender berubah dari waktu ke waktu, dari tempat ke tempat bahkan dari kelas ke kelas, sedangkan jenis kelamin biologis (sex) akan tetap tidak berubah.

Perbedaan gender (gender differences) pada proses berikutnya melahirkan peran gender (gender role). Perbedaan gender ini kemudian menimbulkan terjadinya struktur ketidakadilan seperti marginalisasi, subordinasi, dan bahkan kekerasan (violence) terhadap kaum perempuan. Kekerasan atau penyiksaan terhadap kaum perempuan dapat berupa kekerasan fisik, psikis, maupun kekerasan seksual. Diungkapkan Fakih (2007:150) kekerasan yang bersifat fisik yaitu pemerkosaan, persetubuhan antaranggota keluarga (incest), pemukulan dan penyiksaan, bahkan yang lebih sadis lagi pemotongan alat genital perempuan. Kekerasan dalam bentuk nonfisik yang sering terjadi yaitu pelecehan seksual, menyebabkan ketidaknyamanan bagi perempuan secara emosional.

Pelanggengan posisi subordinasi, stereotype dan kekerasan terhadap perempuan secara tidak sadar juga dijalankan oleh ideologi dan kultur patriarki, yakni ideologi kelelakian. Ideologi ini ada di kepala kaum laki-laki maupun perempuan, juga dalam tafsir agama yang sangat mempengaruhi kebijakan negara dan birokrasi pembangunan (Fakih, 2007:151).

Sebagai penelitian sastra, fokus penelitian adalah mengungkap fenomena kekerasan gender dalam produk sastra/ karya sastra. Sastra dapat merupakan pencerminan/ penggambaran sebuah fenomena sosial yang terjadi di dalam kehidupan masyarakat. Melalui karya sastra, seorang pengarang dapat mengungkapkan problema kehidupan, dalam hal ini pengarang dapat menjadi juru bicara suatu kelompok masyarakat (Goldmann, 1980). Dalam penelitian ini, pengarang menjadi juru bicara kelompok perempuan yang mengalami kekerasan gender. 
Untuk melihat ilustrasi kekerasan gender, khususnya kekerasan terhadap perempuan, penelitian ini difokuskan pada penggambarannya di dalam karya sastra. Seorang pengarang/novelis dianggap mampu menggambarkan secara jernih dan ekspresif makna perubahan dalam kehidupan masyarakat yang merupakan kenyataan sosial. Kehidupan sosial penulisnya juga turut melatari penciptaan sebuah karya sastra (Swingewood, 2000:91).

Karya sastra merupakan hasil strukturasi struktur kategoris subjek pengarang yang terbangun akibat interaksi antar subjek dengan situasi sosial tertentu. Karya sastra sebagai struktur bermakna mewakili pandangan dunia (vision du monde) pengarang, bukan sebagai individu melainkan sebagai golongan masyarakatnya. Oleh karena itu, karya sastra yang merupakan produk budaya manusia tidak dapat dipahami secara utuh jika aktivitas kehidupan masyarakat tempat karya tersebut lahir diabaikan (Goldmann, 2000).

Masalah dalam penelitian ini diungkapkan dengan menggunakan teori strukturalisme genetik, dan kritik sastra feminis yang digunakan sebagai pisau análisis dalam penelitian ini.

Teori strukturalisme genetik dibutuhkan untuk menjembatani keterkaitan antara kondisi sosial masyarakat yang terdapat di dalam data konkret dan kondisi sosial masyarakat yang terdapat dalam novel melalui pandangan dunia pengarang. Teori kritik sastra feminis digunakan sebagai pisau analisis untuk merangkum berbagai kekerasan gender. Namun untuk mengungkapkan berbagai kekerasan gender yang tersebar di dalam karya sastra yang dijadikan objek penelitian, diperlukan juga pengertian atau definisi kekerasan gender, khususnya kekerasan terhadap kaum perempuan.

Deklarasi Perserikatan Bangsa-Bangsa untuk Penghapusan Kekerasan terhadap
Perempuan tahun 1993 menetapkan kekerasan terhadap perempuan sebagai suatu tindakan kekerasan berdasarkan gender yang membahayakan atau mengakibatkan penderitaan fisik, seksual, atau psikologi bagi perempuan, termasuk juga ancaman-ancaman seperti paksaan pencabutan hak, baik yang terjadi di kehidupan masyarakat maupun dalam kehidupan pribadi.

The United Nations Declaration on the Elimination of Violence against Women (1993) defines violence against women as 'any act of gender-based violence that results in, or is likely to result in, physical, sexual or psychological harm or suffering to women, including threats of such acts, coercion or arbitrary deprivation of liberty, whether occuring in public or in private life (Coomarawamy, 2008:2).

Kekerasan fisik dilakukan dengan cara menampar, menggigit, memelintir tangan, menikam, mencekik, membakar, menendang, mengancam dengan benda atau senjata, dan membunuh. Kekerasan ini juga termasuk praktik kekerasan tradisional seperti pemotongan alat kelamin perempuan dan warisan istri (pada praktiknya warisan janda yang ditinggal mati suaminya jatuh ke tangan saudara laki-laki suaminya). Kekerasan seksual dilakukan dengan pemaksaan hubungan seksual melalui ancaman, intimidasi atau paksaan secara fisik, memaksa hubungan seksual yang tidak diinginkan atau memaksa hubungan dengan orang lain. Kekerasan psikis meliputi perlakuan dengan maksud mengintimidasi dan menyiksa/ menganiaya dan menggunakan bentukbentuk ancaman atau perlakuan kejam/ siksaan, kurungan rumah, pengawasan/ penjagaan, ancaman untuk mengambil hak asuh anak-anak, perusakan barangbarang, isolasi, serangan secara lisan, dan penghinaan yang terus-menerus (Coomarawamy, 2008:2). 


\section{METODE}

Tahap-tahap yang dijalani dalam penelitian adalah sebagai berikut: (1) membaca karya sastra dan mengidentifikasi berbagai motif cerita yang memungkinkan untuk diabstraksi sebagai kekerasan gender terhadap perempuan, (2) menganalisis relasi gender yang termuat di dalam karya-karya tersebut, (3) menganalisis kekerasan gender yang mencakup kekerasan fisik, kekerasan psikis, dan kekerasan seksual, (4) menganalisis akar masalah terjadinya kekerasan gender yang mencakup (a) ketimpangan gender, (b) penegakan hukum yang lemah, dan (c) dominasi nilai-nilai patriarkhi. (5) menginventarisasi semua data temuan ke dalam sebuah catatan, (6) menarik kesimpulan, dan (7) menyusun laporan penelitian

Data dan sumber data penelitian ditentukan secara purposive dan didasarkan pada kriteria objek penelitian, yaitu kekerasan gender yang dilakukan oleh laki-laki (ayah, suami, saudara laki-laki) terhadap perempuan. Menurut Nasution (2007: 98), purposive sampling adalah sampel yang dipilih dengan cermat hingga relevan dengan disain penelitian agar dalam (pilihan) itu terdapat wakilwakil dari sumber data dalam penelitian ini, yaitu tiga buah novel karya Amerika karya Danielle Steel (Malice, The Ghost, Journey).

Analisis data dilakukan dengan teknik deskriptif kualitatif melalui kegiatan ketegorisasi, dan inferensi. Kategorisasi digunakan untuk mengelompokkan data berdasarkan kategori yang telah ditetapkan, yaitu kekerasan fisik, kekerasan psikis, dan kekerasan seksual. Inferensi digunakan untuk menginterpretasikan, memahami, dan menyimpulkan hasil penelitian sesuai dengan permasalahan penelitian. Dalam penelitian ini inferensi didasarkan pada kerangka teori kritik sastra feminis dan strukturalisme genetik.

\section{HASIL DAN PEMBAHASAN}

Pada dasarnya kekerasan terhadap perempuan disebabkan oleh anggapan gender yang terjadi di dalam kehidupan masyarakat dengan memposisikan lakilaki superior dan perempuan inferior. Perbedaan gender (gender differences) pada proses berikutnya melahirkan peran gender (gender role). Perbedaan gender ini kemudian menimbulkan terjadinya struktur ketidakadilan seperti marginalisasi, subordinasi, dan bahkan kekerasan (violence) terhadap kaum perempuan (Fakih, 2007: 150).

Hal senada diungkapkan Nandika (2009:45) bahwa dalam kasus-kasus kekerasan terhadap perempuan pada umumnya, terdapat satu ciri khas dimana seorang pelaku tindakan kekerasan tersebut selalu merasa dirinya sebagai lebih kuat dan korbannya sebagai lebih lemah. Hal ini kemudian menimbulkan suatu pemikiran bahwa dalam suatu tindakan kekerasan terhadap perempuan terdapat kontribusi dari suatu mekanisme sosial yang menyebabkan seorang perempuan berada dalam posisi subordinasi dari laki-laki. Dalam perspektif gender, kondisi ini dikaitkan dengan adanya suatu kultur atau budaya patriarki yang sejak awal membentuk peradaban manusia, yang menganggap bahwa laki-laki adalah superior terhadap perempuan dalam kehidupan pribadi, keluarga, masyarakat, dan kehidupan bernegara.

Dari berbagai macam bentuk kekerasan yang menimpa perempuan, bentuk yang paling umum dikategorikan menjadi tiga jenis, yakni kekerasan fisik, psikologis, dan seksual (Nandika, 2009).

\section{Kekerasan Fisik, Psikis, dan Seksual}

Kekerasan fisik dilakukan dengan cara menampar, menggigit, memelintir tangan, menikam, mencekik, membakar, menendang, mengancam dengan benda atau senjata, dan membunuh (Coomarawamy, 2008:2). 
Dalam novelnya Malice, Steel mengungkapkan kekerasan fisik yang dilakukan oleh seorang suami dan ayah terhadap istri dan anak perempuannya. Sebagai seorang suami, laki-laki ini setiap malam memukuli istrinya "...he had beaten her,... night after night,..." (Steel, 2007: 16). Bahkan ketika istrinya sedang hamil, ia tetap menyiksanya dengan kejam. Akibat pukulan-pukulan brutal dan mengerikan yang dilakukannya, perempuan ini mengalami keguguran. Terakhir kali ia mengalami keguguran ketika kandungannya berumur enam bulan dan sejak saat itu perempuan ini tidak dapat mengandung lagi.

"Twice Ellen had miscarried because of the beatings, the last time at six months, and after that, there had been no more children. The beatings had been brutal and terrifying, ..." (Steel, 2007: 16).

Kekerasan tersebut juga disampaikan oleh anak perempuan mereka. Ia bercerita bahwa ayahnya selalu memukuli ibunya. Setiap malam ia memukuli ibunya dengan sekuat tenaga. Ia mendengar teriakan ibunya dan suara hantaman tinju ayahnya. "When I was a little girl, my father beat my mother all the time ... I mean all the time ... every night ... as hard as he could ... I used to hear her screams, and the sound of his fists on her ..." (Steel, 2007: 287). Setiap malam ketika ayahnya pulang, ia berteriak pada ibunya dan perempuan ini menangis, lalu suaminya memukulnya "But every night he'd come home, he'd yell and she'd cry and he'd beat her again." (Steel, 2007: 287). Laki-laki ini tidak hanya melakukan kekerasan fisik terhadap istrinya, ia juga memukuli anak perempuannya He would have beaten Grace, too,.... (Steel, 2007: 16).

Kekerasan terhadap perempuan juga tercermin dalam kehidupan di panti asuhan. Di tempat ini banyak perempuanperempuan yang mengalami kekerasan fisik. Suami mereka dengan kejam menyetrika wajah dan memukul dengan besi.

"Like the woman who'd come in two nights before whose husband had put a hot iron to her face, after hitting her with a tire iron on the back of her head. He had almost killed her, ..." (Steel, 2007:221).

Novel The Ghost menggambarkan kekerasan fisik yang dilakukan oleh seorang suami terhadap istrinya. Laki-laki ini sangat terkenal dengan kekejamannya, sikap kasarnya dan tangannya yang suka memukul dan menampar ... slapping her as often as he dared,... (Steel, 1998:156). Ia kerap memukul istrinya sekalipun perempuan tersebut dalam keadaan hamil. Siksaan laki-laki ini merupakan hal yang dialaminya istrinya sehari-hari. Kekerasan fisik yang dilakukan suami telah mengakibatkan keinginan mereka untuk mempunyai anak belum terkabul. Semua bayi yang pernah dikandung perempuan ini meninggal dalam kandungan atau hanya berumur beberapa jam.

She had failed him bitterly and often. The sixth child she'd borne him, dead at birth this time, had been buried only three months before. The only thing Edward had ever wanted from her was an heir, and after years with her, he still didn't have one. All the children she had borne him had miscarried or been stillborn, or died within hours of their birth (Steel,1998: 155).

Lebih lanjut kekerasan fisik terungkap dalam novel Journey. Melalui novel ini, Steel mengungkapkan kekerasan yang dilakukan oleh seorang suami yang sering menyiksa dan memukul istrinya. Perempuan ini memperlihatkan luka memar di lengannya,"Janet gingerly pulled up her sleeve, and Maddy could see ugly bruises." (Steel, 2001:23). Perempuan ini juga mengalami siksaan dari suaminya ketika ia harus menerima hukuman dengan sengatan listrik he'll put me in a mental institution. He did that once, after my little girl was 
born. They gave me electric shock treatment" (Steel, 2001: 23).

Kekerasan fisik lainnya terungkap melalui tokoh ibu Negara yang menceritakan bagaimana ayahnya melakukan kekerasan terhadap ibunya. Setiap minggu, ayahnya memukul ibunya hingga hal tersebut menjadi pemandangan rutin bagi anak-anak mereka. Tidak hanya ayahnya, tetapi juga saudara laki-lakinya yang melakukan kekerasan terhadap istrinya.

"My father was an alcoholic, and he beat my mother every weekend without fail, after he got paid on Friday. They were married for forty-nine years, until she finally died of cancer. His beating her was something of a ritual for all of us, ..., my brothers went out and got drunk themselves. One of them was abusive to his wife when he grew up, he was the oldest, ... (Steel, 2001: 55-56).

Kekerasan lainnya terungkap melalui seorang anggota komite Anti kekerasan terhadap perempuan. Ia mengungkapkan kekerasan yang dilakukan oleh ayahnya. Ayahnya membunuh ibunya. Kekerasan juga dialami oleh dirinya yang terjadi ketika berusia lima belas tahun ia diperkosa dan dipukuli oleh seorang laki-laki ...her father had killed her mother, ... She said that she had been raped and beaten at fifteen by a boy she had grown up with (Steel, 2001: 56-57).

Korban kekerasan fisik lainnya adalah seorang perempuan yang bekerja sebagai penyiar. Ia mengungkapkan kekerasan yang dilakukan ayahnya. Ayahnya sering menyiksa ibunya dan selalu mengatakan ibunya lah yang bersalah. Bahkan bila ibunya tidak ada, dirinya lah yang menjadi sasaran ayahnya.

"... my father always hit my mother.... sometimes he just did it because he was mad at her, or at someone else, or at something that had happened that day. We were dirt poor, and he never seemed to be able to keep a job, so he hit my mother about that too. Everything that happened to him was always her fault. And when she wasn't around, he hit me, but not very often. Their fighting was kind of the background music to my childhood, a familiar theme I grew up with." (Steel, 2001: 57).

Ia juga mengungkapkan kekerasan yang dilakukan oleh suaminya. Segera setelah menikah, ia senantiasa disalahkan sebagai istri yang tidak baik, bodoh dan ceroboh sehingga kerap kali ia mendapat pukulan dan siksaan dari suaminya. Lakilaki tersebut mematahkan kedua lengannya, ia juga mendorongnya dari tangga hingga istrinya terjatuh, dan suaminya juga mematahkan kakinya.

"... as soon as we were married, he started to beat me up.... when he said that it was all my fault, if I weren't such a pain in the ass and such a bad wife, and so stupid and careless and just plain dumb, he wouldn't 'have' to hit me. But he had to. He broke both my arms once, and he pushed me down the stairs once, and I broke my leg (Steel, 2001: 57-58).

Laki-laki ini juga menyiksa istrinya sehingga bibir dan matanya bengkak dan memar.. "... her lips and eyes were swollen from his latest acts of vengeance" (Steel, 2001: 33).

Kekerasan psikis meliputi perlakuan dengan maksud mengintimidasi dan menyiksa/menganiaya dan menggunakan bentuk-bentuk ancaman atau perlakuan kejam/siksaan, kurungan rumah, pengawasan/penjagaan, ancaman untuk mengambil hak asuh anak-anak, perusakan barang-barang, isolasi, serangan secara lisan, dan penghinaan yang terusmenerus (Coomarawamy, 2008:2).

Dalam novel Malice, Steel sebagai penulis perempuan mengungkapkan pandangan dunianya dengan menampilkan kekerasan psikis yang dilakukan oleh seorang suami. Ia kerap mengancam 
istrinya yang sedang sakit keras. Laki-laki ini menghina istrinya dengan mengatakan perempuan tersebut adalah istri yang tidak berharga. Hal ini dikarenakan penyakit yang dideritanya telah membuatnya tidak dapat lagi menjalankan kewajiban sebagai seorang istri, terutama dalam hal hubungan suami-istri. Laki-laki ini kemudian mengancam akan meninggalkan keluarganya yaitu istri dan anak perempuannya. Tentu saja hal ini tidak mungkin dapat diterima oleh istrinya karena kepergian kepala keluarga sebagai pencari nafkah otomatis akan mengancam perekonomian keluarga. Suami yang kejam ini kemudian memberi syarat kepada istrinya agar ia tidak meninggalkan keluarga, yaitu ia menuntut istrinya agar memberinya kebahagiaan. Kondisi istri yang sedang sakit keras tentunya tidak mungkin dapat memenuhi tuntutan tersebut. Ia kemudian meminta istrinya untuk merelakan anak perempuan mereka satu-satunya yang berusia tiga belas tahun untuk menggantikan posisinya (Steel, 2007:17). Jelas ini merupakan kekerasan psikis yang luar biasa yang dilakukan seorang suami terhadap istrinya. Selain menghina terus menerus, ia juga mengancam, dan membuat istrinya ketakutan.

Kekerasan psikis juga terungkap dalam novel The Ghost. Karya sastra ini menampilkan kekerasan yang dilakukan oleh seorang suami terhadap istrinya. Suami terus menerus mengancam istrinya untuk melahirkan seorang ahli waris baginya. Dikatakannya bahwa ia akan membunuh istrinya apabila ia tidak dapat melahirkan seorang ahli waris baginya. "Then he only threatened..., and telling her he would kill her if she failed to produce an heir". (Steel, 1998:156).

Kekerasan psikis juga terungkap dari sikap suami yang tidak peduli dan tidak setia kepada istrinya. Ia jarang di rumah. Ia lebih sering pergi berburu di tanah miliknya yang sangat luas, mabuk-mabukan di pub, mengganggu gadis-gadis pe- layan, atau menginap di rumah kawankawannya. Jika suami berada di rumah, ia membuat istrinya tersiksa. Yang paling menyedihkan adalah ketika anak pertama mereka meninggal dunia hanya beberapa jam setelah dilahirkan. Anak ini merupakan satu-satunya harapan perempuan ini sehingga ia sangat bersedih. Akan tetapi, sebagai ayah laki-laki ini sama sekali tidak bersedih karena anak itu berjenis kelamin perempuan. Kemudian istrinya hamil lagi tiga kali, semuanya laki-laki. Dua meninggal dunia dalam kandungan dan satu meninggal karena lahir sebelum waktunya. Setelah itu dia mendapat dua anak perempuan. Dua-duanya meninggal dunia ketika dilahirkan. Berjam-jam perempuan malang ini memeluki bayi terakhirnya. Kepedihan hatinya hampir membuatnya gila. Seorang pelayan akhirnya mengambil bayi itu dari pelukannya lalu menguburkannya. Namun suaminya sejak saat itu malah hampir tidak pernah mengajaknya bicara (Steel, 1998:156).

Sikap tidak setia laki-laki ini terungkap dengan dimilikinya tujuh anak haram yang semuanya laki-laki. Gadis-gadis muda dengan mudah jatuh ke pelukannya. Mereka akan diperkosa, diperalat, dan dicampakkan begitu saja setelah ia bosan. Dia tak pernah peduli jika karena perbuatannya gadis-gadis itu hamil dan melahirkan anaknya (Steel, 1998: 157).

Namun ia tetap menginginkan seorang ahli waris yang sah yang lahir dari rahim istrinya yang sah. Ia tidak ingin mewariskan gelar dan hartanya kepada salah satu anak haramnya atau kepada adik tirinya. Ia terus menuntut dan mengancam istrinya untuk memberinya seorang ahli waris seperti katanya, "I will leave you nothing." ... "I will kill you before I let you live on the face of this earth without me, if you do not give me an heir" (Steel, 1998: 157).

Lebih lanjut, kekerasan psikis terungkap dalam novel Journey. Kekerasan ini dilakukan oleh seorang suami yang menuntutnya untuk mengikat saluran 
telurnya karena ia tidak ingin mempunyai anak. Dengan demikian perempuan ini tidak mungkin lagi mempunyai anak.

Jack had insisted that she has her tubes tied when they got married. Between the two of them they had seen to it that she would never have children. They had both convinced her that it was the best thing for her, and she'd believed them. She not only felt devastated suddenly, but incredibly stupid for listening to them. They had both deprived her of the chance to have kids (Steel, 2001: 138).

Sebagai suami, laki-laki ini kerap menghina istrinya dengan menyebutnya "sampah kulit putih". Ketika istrinya tidak menyukai panggilan tersebut, suami mengatakan bahwa itu adalah kenyataan "..., and he called her "poor white trash" when he wanted to really tease her. She didn't love it, but it was true" (Steel,2001:75). Suami juga menghinanya dengan mengatakan bahwa istrinya bukanlah orang yang berpendidikan, bahkan tidak tamat sekolah menengah sehingga perempuan tersebut kurang dapat berpikir baik.

"It's the truth. As I recall, Mad, you never went to college. In fact, I'm not even sure if you finished high school." It was the ultimate put-down, insinuating that she was too stupid and uneducated to think. He said it to humiliate her, ...(Steel, 2001:149).

Laki-laki ini juga menghina dan merendahkan istrinya dengan mengatakan bahwa setiap gadis udik mirip dengannya. Dengan rambut hitam dan mata biru bukanlah hal yang istimewa "Every hick in Tenneesee looks like you, for chrissake. You think black hair and blue eyes is so unsual? They all look like you, Maddy. You're not special" (Steel, 2001:186). Lebih lanjut laki-laki ini menuduh istrinya sebagai pelacur murahan sejak ia berusia dua belas tahun. "You're a whore, Mad, a cheap slut. You must have been out fucking around when you were twelve, for chrissake" (Steel, 2001:
319). Ketika perempuan ini menyanggah pernyataan suaminya tersebut dengan mengatakan "I'm not a slut from Knoxville. I never was. Even back then when I was poor and unhappy." (Steel, 2001: 319), suami menyambut sinis dengan mengatakan "Bullshit. I don't recall that you were ever from the right side of the tracks, or even knew what they looked like. Hell, you were a whore when you were a kid. Look at Lizzie..."You owe me everything. And I hope you realize you'll be out of a job if you leave me" ( Steel, 2001: 319).

Kekerasan psikis lainnya terungkap ketika suami melarang istrinya bertemu dengan putrinya tunggalnya. Bahkan laki-laki ini melecehkan putrinya dengan mengatakan gadis itu pun pelacur seperti ibunya, dan ia tidak dapat menerimanya sekali pun istrinya memohon kepadanya hingga ia merasa frustrasi.

"And just to make things clear, don't try bringing your little brat around here. She's probably a whore, just like her mother. She's my daughter!" Maddy shouted at him in total frustration. I have a right to see her if I want to, and I live here. Only for as long as I say you do, and don't you forget that." (Steel, 2001:189).

Kekerasan seksual dilakukan dengan pemaksaan hubungan seksual melalui ancaman, intimidasi atau paksaan secara fisik, memaksa hubungan seksual yang tidak diinginkan atau memaksa hubungan dengan orang lain (Coomarawamy, 2008:2).

Kekerasan seksual terungkap dengan jelas dalam novel Malice. Kekerasan dilakukan oleh seorang ayah terhadap anak perempuannya sendiri. Anak perempuan yang baru berusia tiga belas tahun ini dengan sangat terpaksa harus rela menjadi budak seks ayah kandungnya sendiri. Hal ini dilakukan demi keutuhan keluarga dan menolong ibunya yang sedang sakit keras "That night, they came into her room, and her mother helped him. She held her down, 
and crooned to her, and told her what good girl she was, and how much they loved her" (Steel, 2007: 18). Ketika gadis ini menolak keinginan ayahnya, laki-laki kembali ke kamarnya dan menyiksa ibunya yang sedang sakit keras. Tak kuasa menyaksikan siksaan yang harus ditanggung ibunya, anak perempuan ini menyerah dengan histeris ia mengatakan bahwa ia bersedia menuruti semua kehendak ayahnya demi ibunya.

'But anytime Grace didn't cooperate with him, or do everything he asked, he went back to his own room and beat up her mother, no matter how sick she was, or how much pain she was in.... and she would run shrieking into their room, and swear that she'd do anything he wanted. And over and over and over again, he made her prove it (Steel, 2007:18).

Kekerasan ini terus berlangsung selama empat tahun. Anak perempuan ini telah menjadi budak seks ayah kandungnya sendiri. Setelah ibunya meninggal dunia, ternyata kekerasan terhadap anak perempuan ini tidak berakhir. Ketika ia berusaha untuk mengakhirinya, menolak keinginan ayahnya, ditatapnya anak itu dengan mata berapi-api, dan dicengkeramnya lengan anak itu lebih keras. Anak perempuan tersebut mengerang halus waktu ayahnya menyeretnya dari tempat tidur. Dia terpaksa mengikutinya walaupun dadanya terasa perih.

"His eyes burned into hers as he looked down at her, and grabbed her harder. "Yes, you can, and you're going to, dammit. I told you to come into my room." "Dad, please ..." Her voice was a thin whine, as he dragged her from the bed, and she followed him unwillingly into his bedroom.... she could feel her chest tighten and hear the beginnings of a wheeze as she begged him (Steel, 1998:15).

Anak perempuan malang ini setiap hari harus menerima kekerasan seksual karena setiap malam ayahnya memperkosanya. "... and then raped me. It was always rape (Steel, 2007: 288). Bahkan ayahnya dengan kasar memperkosanya seperti dikatakannya

"... all I need is you, little Grace ... all I need is my baby who loves me so much, and whom I love ... With a single hand, he dropped his trousers and stepped out of them, along with his shorts, and he stood naked and erect before her".(Steel, 2007:16).

Kekerasan seksual yang dilakukan ayahnya ini sangat menyiksa gadis tersebut karena ayahnya memperkosanya dengan kekerasan yang luar biasa. Ayahnya menindihnya dengan tubuhnya yang kuat, lalu dengan kasar menggaulinya. Gadis tersebut merasa lebih kesakitan daripada biasanya. Sesaat dikiranya ayahnya akan membunuhnya. Ayahnya seakan-akan meninjunya dari dalam, untuk menunjukkan padanya bahwa dia menguasainya dan bisa berbuat sesuka hatinya. Sakitnya tak tertanggungkan, gadis tersebut merasa akan pingsan. Kamar seperti berputar-putar, dia mengambang dalam keadaan hampir mati, sementara ayahnya berkali-kali melakukan perbuatan keji itu.

"...he pinned her down with his powerful arms, and the weight of his body. Her legs were swiftly parted by his own, and the familiarity of him forced his way through her with more pain than she had ever known or imagined. For a moment, she almost thought he might kill her. It had never been this way before, he had neve hurt her as much as he did now. It was as though he were beating her wih a fist from inside this time, and wanted to prove to her that he owned her and could do anything he wanted. It was almost beyond bearing and for an instant she thought she might faint, as the room swirled around her, and he hammered at her again and again, tearing at her breasts, chewing at her lips, 
forcing himself into her again and again, until she seemed to drift in a half state near death, wishing that finally, mercifully, he would kill her (Steel, 2007:20).

Kekerasan seksual juga tergambar dalam kehidupan di sebuah yayasan penampungan perempuan dan anak-anak yang bermasalah. Di tempat ini tampak perempuan-perempuan korban kekejian seperti gadis-gadis berumur empat belas tahun yang hamil karena diperkosa oleh ayah, abang, atau paman mereka. "There were pregnant fourteen-year-olds who had been raped by their fathers or brothers or uncles,..." (Steel, 2007: 157).

Novel The Ghost mengungkap kekerasan seksual ketika seorang istri merasa diperkosa oleh suaminya sendiri. Setelah delapan tahun menikah, istrinya telah kehilangan semangat hidup, harapan, dan impian. Harga dirinya terluka. Ia merasa terhina dan tersiksa karena laki-laki yang dibencinya sering memperkosanya dan memaksanya mengandung seorang ahli waris yang sah baginya.

She had no life, no hope, no dreams. She was beaten, abused, detested, scorned, by a man she loathed, and with whom she had been forced to sleep for the past eight years, and constantly try to give him children, above all an heir (Steel, 1998: 157).

Kekerasan yang sama juga terungkap dalam novel Journey. Kekerasan dilakukan oleh seorang suami yang memperlakukan istrinya seperti mesin seks miliknya dan dapat 'digunakannya' setiap saat ia menginginkan tubuhnya.

"He wanted her body day and night. She was beginning to feel like a sex machine, and once or twice, while they made love, he had reminded her that he 'owned' her. She didn't like the term, but it seemed to turn him on to say it to her, so she didn't say anything to him" (Steel, 2001: 116).
Kenyataan ini terlihat ketika mereka berlibur selama lima hari. Di tempat yang cukup terpencil, suaminya terus menerus memaksanya untuk bercinta hingga istrinya tidak berdaya lagi. Ia merasa kepalanya berputar-putar, bahkan ia nyaris tidak bisa duduk. Saat itu perempuan malang ini merasakan kemarahan, kekejaman, dan penghianatan yang harus ia terima dari suaminya.

..., and it was just secluded enough for him to make love to her, which he did repeatedly. ... And at times, Maddy felt as though her head were spinning. It was as though everything she had felt before, the anger, the outrage, the betrayal, had been some kind of a delusion, and this was the only reality she knew. They were there for five days, and she hated to leave as the end of it, and go to London.... And he had never made love to her as often. She could hardly sit down by the time they got to London (Steel, 2001:115).

Setelah mengawalinya dengan pernyataan bahwa ia 'memiliki' dan mencintainya, mereka bercinta dengan cara yang tidak biasa. Laki-laki ini menyiksa istrinya hingga ia menjerit kesakitan, payudaranya mengeluarkan darah dan perempuan ini pun 'teler' sampai ia tak mampu lagi untuk menangis.

"Who owns you, Mad ...who loves you? ...I own you ...I love you... Say it, Maddy,..." "I love you ... you own me ..." He was turning her inside and outside in, and she said the words, he began making love so hard that he hurt her. She gave a small squeak of pain, and tried to move away from him, and he held her pinned down to the floor with all his might, and continued pounding into her as she murmured in pain, but he wouldn't stop, he only pounded harder. She tried to say something to him, and he crushed his mouth down on hers, as he pounded her into the floor as hard as he could, and then he came with a great shuddering, and as 
he did, he reached down and bit her nipple. It was bleeding when he finally stopped, and she was too dazed to even cry (Steel, 2001:112).

Ketika darah menetes dari payudaranya, perempuan ini merasa tubuhnya remuk, kepalanya pusing tak berdaya. Sungguh siksaan yang sangat luar biasa yang telah dilakukan suaminya. Perempuan ini tak mampu berpikir lagi, ia merasa begitu berat siksaan yang harus ia terima walaupun kemudian suaminya merasa bersalah dan meminta maaf atas perlakuan kasarnya tersebut.

... he pinched her nipples hard, too hard, and then without another word, he grabbed her, and showed her who was in control. It was never Maddy, always Jack. She was beginning to think that power and control were all that mattered to him (Steel, 2001:70).

Pada kesempatan lain, Suami yang kejam ini kembali melakukan kekerasan terhadap istrinya. Dengan kasar ia mendorong istrinya ke dinding, menyeretnya ke kamar mandi dan bercinta di lantai tanpa menghiraukan permohonan istrinya untuk menghentikannya.

... the moment they got back to their suite and closed the door, he slammed her against the wall, pulled down her pants, and nearly raped her. She tried to make him wait, or go into the bedroom with her, but he shoved her against the wall and wouldn't stop, and then he dragged her into the bathroom and took her on the marble floor, while she begged him to stop. He was hurting her again, but he was so excited he didn't hear her (Steel, 2001:116).

\section{Akar Masalah Terjadinya Kekerasan Gender}

Feminisme adalah sebuah ideologi pembebasan perempuan karena yang melekat dalam semua pendekatannya adalah keyakinan bahwa perempuan mengalami ketidakadilan karena jenis kelaminnya. Di bawah payung lebar, feminisme menawarkan berbagai analisis mengenai penyebab, pelaku, dari penindasan perempuan (Humm, 2002: 158). Hal senada disampaikan Fakih (2007) bahwa perbedaan gender telah melahirkan ketidakadilan, terutama terhadap perempuan. Menurutnya, salah satu kekerasan terhadap satu jenis kelamin tertentu disebabkan oleh anggapan gender. Pada dasarnya, kekerasan gender disebabkan oleh ketidaksetaraan kekuatan yang ada dalam masyarakat, lemahnya penegakan hukum, dan dominasi nilai-nilai patriarkhi.

Dominasi nilai-nilai patriaki yang melahirkan ketimpangan gender menetapkan suami adalah kepala keluarga yang mencari nafkah sementara istri adalah ibu rumah tangga yang bertugas mengurus anak-anak dan melayani suami. Keadaan ini kemudian menyebabkan terjadinya kekerasan terhadap perempuan. Hal ini terungkap ketika suami dengan label superior dapat melakukan kekerasan fisik, psikis dan seksual terhadap anggota keluarganya seperti istri dan anak perempuan yang diberi label inferior. Laki-laki ini senantiasa menyiksa istri dan anaknya, menghina istrinya sebagai istri yang tidak berguna karena tidak mampu memberikan kebahagiaan kepada suami. Laki-laki yang berperan sebagai pencari nafkah dapat mengancam istri dan anaknya yang sangat tergantung kepadanya dalam hal ekonomi. Keadaan ini kemudian menjadi akar masalah terjadinya kekerasan, baik kekerasan fisik, psikis, maupun seksual yang dilakukan oleh seorang suami dan ayah terhadap istri dan anak perempuannya seperti terungkap dalam novel Malice sebagai berikut.

Her own father had beaten her too, and at first what John did, didn't seem so unusual or so awful. But it got worse over the years, and at times he threatened to leave her because she was so worthless. He made her do any thing he wanted just so he wouldn't leave her. And as Grace grew up 
and grew more beautiful each day, it was easy to see what he wanted, what would be required of her, if she really wanted to keep him.... He told her bluntly then that if she expected to stay married to him something would have to be worked out to keep him happy. It was obvious that she couldn't keep him happy anymore, couldn't give him what he wanted. But Grace could. She was thirteen, and so very lovely (Steel, 1998: 17).

Keadaan ini juga terungkap ketika perempuan senantiasa merasa bersalah dan berusaha menyembunyikan kekerasan yang dilakukan suaminya. Ia berbohong dengan dengan mengatakan bekas-bekas siksaan suaminya adalah akibat benturan ketika ia terjatuh. Istri tidak berusaha untuk menyudahi kekerasan tersebut, ia hanya menerima semua kekerasan sebagai takdir yang harus diterima oleh perempuan dengan posisinya yang inferior.

Before that, he had beaten her, and Grace had listened to it, night after night, in her bedroom, sobbing, and listening to them, and in the morning, her mother would try to explain the bruises, talking about how she had fallen, or walked right into the bathroom door, or slipped, but it was no secret. They all knew. No one would have believed John Adams capable of it, but he was, and a great deal more. He would have beaten Grace, too, except that Ellen never let him. Instead, she had offered herself up, time after time, for his beatings, and told Grace to lock the door to her room (Steel, 1998: 17).

Dalam kehidupan keluarga, istri harus menerima suami yang tidak setia karena senantiasa selingkuh hingga mempunyai beberapa anak haram. Suami juga sangat kejam karena sikapnya kasar dan gemar memukul dan menampar istrinya. Suami juga melakukan kekerasan seksual dengan cara 'memperkosanya' terus menerus seperti terungkap dalam novel The Ghost. Dominasi nilai-nilai patriarkhi telah menyebabkan perempuan korban kekerasan merasa dirinyalah yang bersalah karena ia gagal melahirkan seorang ahli waris yang diinginkan suaminya. Artinya patriarkhi telah menjadi akar masalah terjadinya kekerasan yang dilakukan laki-laki karena sekalipun ia telah melakukan kejahatan secara fisik, psikis, maupun seksual, ia tetap dalam posisi tidak bersalah.

She knew Edward well, had known him for a long time. She knew his cruelty, his infidelity, and his unkindness, the merciless of his tongue, and the viciousness of the back of his hand. She had failed him bitterly and often. The sixth child she'd borne him, dead at birth this time, had been buried only three months before. The only thing Edward had ever wanted from her was an heir, and after years with her, he still didn't have one. All the children she had borne him had miscarried or been stillborn, or died within hours of their birth (Steel,1998:154-155).

Dominasi nilai-nilai patriarkhi yang menimbulkan ketimpangan gender dan melemahkan penegakan hukum juga terungkap dalam novel Journey. Dengan posisinya sebagai suami yang superior, suami dapat dengan kejam menyiksa dan menyakiti istrinya. Ia juga dapat mengendalikan dan memutuskan segalanya. Ia senantiasa menghina dan mengisolasi istrinya dari lingkungannya serta mengancamnya seperti terungkap dalam pernyataan seorang istri sebagai berikut.

"...he's cruel, and abusive, and he hurts me. Intentionally, I think. He controls me. Contantly. He makes all my decisions for me. He calls me poor white trash, reminds me that I'm uneducated, and tells me that if he fired me, I'd go right down the tubes and no one would ever hire me. He doesn't let me have friends, he isolates me. He makes me feel like dirt. He lies to me, and belittles me, and makes me feel 
rotten about myself. He humiliates me, and lately he frightens me. He's getting rougher in bed, and he threatens me ..." (Steel, 2001: 162).

\section{SIMPULAN}

Berdasarkan analisis kekerasan gender dalam penelitian ini, terdapat simpulan sebagai berikut. Pertama, ketiga novel Malice, The Ghost, dan Journey mengungkap kekerasan gender yang mencakup kekerasan fisik, psikis, dan seksual dengan perempuan sebagai korban. Kedua, akar masalah kekerasan terhadap perempuan mencakup (a) ke-timpangan gender, (b) penegakan hukum yang lemah, dan (c) dominasi nilai-nilai patriarkhi.

\section{UCAPAN TERIMA KASIH}

Artikel ini merupakan salah satu produk penelitian Hibah Bersaing, Dikti, tahun 2015. Oleh karena itu, disampaikan ucapan terima kasih kepada Direktur DP2M, Dikti yang telah membiayai penelitian ini. Terima kasih juga disampaikan kepada Rektor Universitas Nasional melalui Lembaga Penelitian dan Pengabdian kepada Masyarakat Universitas Nasional yang telah memfasilitasi penelitian ini sehingga semua proses penelitian dapat berjalan sesuai ketentuan. Selanjutnya, disampaikan ucapan terima kasih kepada reviewer yang telah memberi masukan dan catatan penting untuk penyempurnaan tulisan ini.

\section{DAFTAR PUSTAKA}

Coomaraswamy, R. 2008. Domestic Violence Against Women and Girls. Innocenti Digest No. 6 (Unicef)

Fakih, M, 2007. Analisis Gender \& Transformasi Sosial. Yogyakarta: Pustaka Pelajar Offset.

Goldman, L. 1980. Method in the Sociology of Literature. England: Basil Blackwell Publisher.

Humm, M. 2002. Ensiklopedia Feminisme. Terjemahan Mundi Rahayu. Jakarta: Fajar Pustaka.

Madsen, D L. 2000. Feminist Theory and Literary Practice. London: Pluto Press.

Mascia, F E. - Lees \& Nancy J. B. 2000. Gender and anthropology. United States of America: Waveland Press, Inc.

Nandika, A G. 2009. "Suatu Kajian Kriminologis Mengenai Kekerasan terhadap Perempuan dalam Relasi Pacaran Heteroseksual". Dalam Jurnal Kriminologi Indonesia Volume 5 Nomor 1.

Nasution, S. 2007. Metode Research (Penelitian Ilmiah). Jakarta: Bumi Aksara.

Steel, D. 2001. Journey. New York: Dell Publishing a Division of Bantam Doubleday Dell Publishing Group, Inc.

Steel, D. 2007. Malice. New York: Dell Publishing a Division of Bantam Doubleday Dell Publishing Group, Inc.

Steel, D. 1998. The Ghost. New York: Dell Publishing a Division of Bantam Doubleday Dell Publishing Group, Inc.

Swingewood, A. and Diana L. 2000. The Sociology of Literature. London: Collier MacMillan Publisher. 